\title{
ANALISIS PENGARUH PERGERAKAN BURSA INTERNASIONAL TERHADAP PERGERAKAN BURSA INDONESIA
}

\author{
Johan Halim ${ }^{1}$ \\ PT. Bank Mandiri \\ Marcories $^{2}$
}

BINUS Business School, Jakarta

\begin{abstract}
The purpose of this study was to determine and obtain empirical evidence on whether there is influence and reciprocal relationships on the movement of international exchanges (Dow Jones, FTSE, Nikkei, Straits Times and Hang Seng), economic conditions, and the relationship between the state of the market movements Indonesia (JSX and IDX). Method of multiple linear regressions with Eviews 5.1 program used in this study to determine the effect of the variables mentioned above. The sample in this study includes daily data for the JSX ongoing since January 1, 2006 through December 31, 2008, and taken to IDX data starting from January 1, 2009 through June 30, 2009.

Results of this study are contained influences of the international exchanges separately. No effect occurs when tested simultaneously. JSX influenced by outside markets, but otherwise IDX positively affect international markets. IDX was due to the influence of the shifting influence of the American economy, which affected Subprime Mortgage crisis and the market is already pretty saturated, to Asia which is devoted to research in Indonesia, which is not affected by the Subprime Mortgage and developing countries (developing countries) that could affect other markets Subprime Mortgage crisis affected.

Conclusion that there was a shift in which the effect of Indonesia's market affect other markets in the same region even European markets (FTSE)
\end{abstract}

\footnotetext{
${ }^{1}$ Senior Manager Strategy \& Performance Group of PT. Bank Mandiri, johan.halim@bankmandiri.co.id

${ }^{2}$ Alumni of BINUS Business School 
and the U.S. (Dow Jones) due to the improvement in the economic situation of Indonesia that resilience to the global crisis.

Keywords: JSX, IDX, Dow Jones, FTSE, Nikkei, Strait Times, Hangseng.

\begin{abstract}
ABSTRAK
Tujuan penelitian ini adalah untuk mengetahui dan memperoleh bukti empiris mengenai ada tidaknya pengaruh dan hubungan timbal balik atas pergerakan bursa internasional (Dow Jones, FTSE, Nikkei, Strait Times, dan Hangseng), kondisi ekonomi, dan hubungan antar negara terhadap pergerakan bursa Indonesia (JSX dan IDX).

Metode uji regresi linear berganda dengan program Eviews 5.1 digunakan dalam penelitian ini untuk mengetahui pengaruh dari variabel-variabel yang telah disebutkan di atas. Sampel dalam penelitian ini meliputi data harian yang berkesinambungan untuk JSX terhitung sejak tanggal 1 Januari 2006 sampai dengan 31 Desember 2008, dan untuk IDX data yang diambil dimulai dari tanggal 1 Januari 2009 sampai dengan 30 Juni 2009. Hasil penelitian ini adalah terdapat pengaruh dari bursa-bursa internasional tersebut secara terpisah. Tidak terjadi pengaruh apabila diuji secara bersamaan. JSX dipengaruhi oleh bursa luar, tetapi IDX sebaliknya mempengaruhi bursa internasional secara positif. Pengaruh IDX tersebut disebabkan bergesernya pengaruh ekonomi Amerika ,yang terdampak krisis Subprime Mortgage serta market yang sudah cukup jenuh, ke Asia yang dalam penelitian ini dikhususkan di Indonesia yang tidak terpengaruh dampak Subprime Mortgage tersebut dan sedang berkembang (negara berkembang) sehingga dapat mempengaruhi bursa lain yang terdampak krisis Subprime Mortgage.

Kesimpulan yaitu terjadi pergeseran pengaruh dimana bursa Indonesia mempengaruhi bursa lain dalam regional yang sama bahkan bursa Eropa (FTSE) dan Amerika (Dow Jones) yang disebabkan membaiknya keadaan ekonomi Indonesia yang dinilai dari ketahanannya menghadapi krisis global.
\end{abstract}

Kata kunci : JSX, IDX, Dow Jones, FTSE, Nikkei, Strait Times, Hangseng. 


\section{PENDAHULUAN}

Krisis keuangan global yang disebabkan oleh subprime mortgage di Amerika Serikat dan Uni Eropa telah mengakibatkan bangkrutnya raksasa keuangan di dunia, dimana berdampak tidak hanya kepada pihak swasta, tetapi juga pihak pemerintah. Institusi keuangan yang sudah bangkrut antara lain Lehman Brothers (Amerika), Fannie Mae, dan Freddie Mac. Hal ini tentu saja membawa dampak negatif bagi kondisi perekonomian dan pasar modal Amerika Serikat dan juga negara lain di dunia. Sebagai buktinya, indeks Dow Jones yang sempat menyentuh level tertinggi di 14.093, terpuruk sampai di level 6.547 pada tanggal 9 Maret 2009 (www.finance.yahoo.com).

Penurunan indeks Dow Jones tentunya berdampak buruk bagi seluruh bursa di dunia, karena indeks Dow Jones yang merupakan acuan kondisi perekonomian Amerika Serikat, secara tidak langsung menjadi acuan bagi kondisi perekonomian global. Dampak negatif akibat penurunan perekonomian Amerika tersebut berpengaruh terhadap perekonomian negara besar lain yang ditandai dengan penurunan indeks pasar saham (www.finance.yahoo.com) seperti, indeks FTSE (Inggris) sempat berada di level 3.512 pada tanggal 3 Maret 2009, dimana mencapai puncaknya di level 6.730 pada 12 Oktober 2007; indeks Hangseng (Hongkong) sempat berada di level 12.525 pada tanggal 9 Maret 2009, dimana mencapai level tertinggi di 31.587 pada tanggal 29 Oktober 2007; indeks Nikkei sempat menyentuh level 7.055 pada tanggal 10 Maret 2009, dimana sebelumnya berada pada level tertinggi 18.188 pada tanggal 19 Februari 2007; Sedangkan untuk indeks Straits Times (Singapore) sempat berada pada level 3.857 pada tanggal 8 Oktober 2007 sebelum terpuruk ke level 1.513 pada tanggal 2 Maret 2009. Penurunan angka indeks tersebut sudah sangat mengkhawatirkan baik bagi pelaku ekonomi di sektor keuangan maupun di sektor riil.

Banyak hal yang dilakukan negara maju di dunia untuk mencegah penurunan bursa saham lebih lanjut lagi, seperti aksi bailout sebesar \$700 milyar oleh pemerintah Amerika Serikat untuk memperbaiki sektor perbankan, penurunan suku bunga secara serentak oleh para gubernur bank sentral di dunia, pemberian insentif bagi sektor-sektor ekonomi tertentu, tetapi respons yang diharapkan masih belum tercapai. Para 
investor dan pelaku ekonomi sangat khawatir mengenai ancaman terulangnya kembali krisis moneter seperti yang terjadi di tahun 1997, sehingga tekanan dan aksi jual saham terus mendorong penurunan bursa saham (http://www.gemadepok.com/).

Di sisi lain, saat ini dampak globalisasi serta revolusi dalam informasi dan teknologi telah dapat dibuktikan secara nyata. Liberalisasi ekonomi akibat dari globalisasi telah membuat capital flow melampaui batas negara, setiap investor dapat berinvestasi dimana saja dan kapan saja. Perdagangan antara negara-negara di dunia sudah menjadi hal yang lazim dilakukan dalam era globalisasi ini. Perekonomian suatu negara banyak dipengaruhi oleh perkembangan perekonomian negara lain. Perekonomian negara maju memiliki kecenderungan mempengaruhi perekonomian negara berkembang dan negara tertinggal.

Indeks harga saham sangat berpengaruh dalam ekonomi suatu negara, begitu pula berlaku sebaliknya. Dari penelitian sebelumnya dalam jurnal dengan judul "Pengaruh Tingkat Bunga SBI, Nilai Kurs Dollar As, dan Tingkat Inflasi Terhadap Indeks Harga Saham Gabungan (IHSG)“ disimpulkan bahwa indeks bursa saham dapat terkoreksi oleh inflasi di suatu negara, begitu pula halnya dengan kemajuan industri yang berpengaruh positif terhadap perbaikan harga saham industri tersebut yang akan berpengaruh langsung terhadap pergerakan indeks harga saham. (http://jurnalskripsitesis.wordpress.com/)

Indeks Harga Saham Gabungan (JSX dan IDX) di Bursa Efek Indonesia (BEI) sebagai salah satu variabel ekonomi makro, selain dipengaruhi oleh harga saham lokal tentu saja dipengaruhi oleh indeks harga saham di negara-negara lain yang lebih maju. Hal ini dapat disimpulkan dari artikel pada website: http://fdib.tripod.com/ yang menunjukkan beberapa bukti korelasi tersebut yang dimana akan diteliti lebih lanjut dalam penelitian ini, yang juga disebutkan dalam artikel pada TEMPO Interaktif (http://www.tempointeraktif.com/).

Globalisasi pasar modal menyebabkan kejadian yang ada di luar negeri mempengaruhi pasar modal dalam negeri. Hal ini terbukti ketika penurunan indeks di dunia berpengaruh pada penurunan indeks JSX atau IDX di BEI dan Indonesia sebagai emerging market terkena dampak tidak langsung dari krisis subprime mortgage. Selain itu, ekspor Indonesia ke 
negara-negara Eropa dan Amerika yang berkurang akibat resesi dunia pada akhir 2008 lalu berpengaruh terhadap penurunan indeks JSX atau IDX di BEI, demikian halnya dengan penurunan impor produk-produk dari RRC yang berdampak tidak langsung terhadap JSX atau IDX di BEI (http://www.wartaekonomi.co.id/). Indeks JSX yang pernah mencapai level tertingginya di 2.838, pada akhir 2008 mencapai titik terendahnya pada level 1.111 di tanggal 28 Oktober 2008.

Berdasarkan latar belakang permasalahan di atas, maka penulis tertarik untuk melakukan uji empiris mengenai pengaruh pergerakan bursa internasional terhadap bursa domestik beserta faktor-faktor yang mempengaruhi dalam penelitian dengan judul "ANALISIS PENGARUH PERGERAKAN BURSA INTERNASIONAL TERHADAP PERGERAKAN BURSA INDONESIA”.

\section{PERUMUSAN MASALAH}

Mengacu pada latar belakang penelitian ini, penulis mengidentifikasi permasalahan yang berkaitan dengan pergerakan JSX dan IDX di BEI sebagai berikut:

1. Pengaruh dari pergerakan indeks harga saham pada bursa internasional terhadap pergerakan indeks JSX \& IDX di BEI.

Globalisasi ekonomi telah menyebabkan hubungan ekonomi antar negara menjadi tanpa batas, sehingga perubahan kondisi ekonomi di satu negara akan memberikan efek bagi negara lain, tentunya ini juga berlaku untuk bursa saham.

2. Perbedaan pengaruh dari indeks pada bursa internasional terhadap pergerakan JSX \& IDX di BEI.

Perekonomian suatu negara cenderung mengikuti trend global dan trend regional terutama trend di negara maju yang menjadi benchmark perekonomian dunia. Perbedaan hubungan ekonomi antara masingmasing negara akan memberikan pengaruh yang berbeda terhadap pergerakan di bursa saham. 


\section{LANDASAN TEORI}

Menurut Darmadji (2006, p1), pasar modal merupakan pasar untuk berbagai instrument keuangan jangka panjang yang bisa diperjualbelikan, baik dalam bentuk utang, ekuitas (saham), instrumen derivatif, maupun instrumen lainnya.

Menurut Siamat (2004, p249), pasar modal dalam arti sempit adalah tempat yang terorganisasi di mana efek-efek diperdagangkan yang disebut bursa efek. Bursa efek atau stock exchange adalah suatu sistem yang terorganisasi yang mempertemukan pembeli dan penjual efek yang dilakukan baik langsung maupun dengan menempatkan wakil-wakilnya. Fungsi bursa efek ini antara lain menjaga kontinuitas pasar dan menciptakan harga efek yang wajar melalui mekanisme permintaan dan penawaran.

Pengertian pasar modal menurut Jogiyanto dalam bukunya yang berjudul “Teori Portofolio dan Analisis Investasi” (2000, p11) adalah merupakan sarana perusahaan untuk meningkatkan kebutuhan dana jangka panjang dengan menjual saham atau mengeluarkan obligasi.

Pengertian capital market menurut Business Dictionary (www.businessdictionary.com) adalah :

"Financial market that works as a conduit for demand and supply of (primarily) long-term debt and equity capital. It channels the money provided by savers and depository institutions (banks, credit unions, insurance companies, etc.) to borrowers and investees through a variety of financial instruments (bonds, notes, stocks) called securities. A capital market is not a compact unit, but a highly decentralized system made up of three major parts: (1) stock market, (2) bond market, and (3) money market. It also works as an exchange for trading existing claims on capital in the form of shares."

Pengertian tersebut dapat diterjemahkan sebagai berikut:

"Pasar finansial yang dijadikan sebagai perantara untuk mempertemukan permintaan dan penawaran (terutama) utang jangka panjang dan modal. Dimana pasar modal ini menyalurkan 
dana yang dimiliki penyandang dana pribadi dan institusi keuangan (bank, kreditur, perusahaan asuransi, dll) kepada debitur dan investee melalui berbagai produk-produk finansial (bonds, notes, saham) yang disebut sekuritas. Pasar modal adalah sebuah institusi yang terdesentralisasi yang terdiri dari tiga bagian utama, yaitu: (1) pasar saham, (2) pasar bond, dan (3) pasar uang. Selain itu, pasar modal dapat diartikan sebagai tempat pertukaran perdagamngan kepemilikan modal dalam bentuk saham.”

Pengertian pasar modal secara khusus menurut Keputusan Menteri Keuangan RI No.1548/KMK/90 adalah suatu sistem keuangan terorganisasi, termasuk di dalamnya adalah bank-bank komersial dan semua lembaga perantara di bidang keuangan, serta keseluruhan suratsurat berharga yang beredar.

Undang-undang pasar modal nomor 8 tahun 1995 memberikan pengertian yang lebih terarah mengenai pasar modal. Pasar modal merupakan tempat untuk melaksanakan kegiatan yang bersangkutan dengan penawaran umum dan perdagangan efek dari perusahaan publik yang berkaitan dengan efek yang diterbitkannya, serta lembaga dan profesi yang berkaitan dengan efek.

Dari seluruh pengertian di atas, penjelasan tentang pasar modal dapat dirangkum menjadi suatu sistem keuangan terganisasi yang menjadi pasar tempat mempertemukan pembeli dan penjual berbagai instrumen keuangan jangka panjang, seperti utang jangka panjang dan modal, yang dapat diperjualbelikan baik dalam bentuk utang, ekuitas (saham), dan instrumen derivatif.

Dari sumber website IHSG (http://www.idx.co.id/), Indeks Harga Saham Gabungan (disingkat IHSG, dalam bahasa Inggris disebut juga Jakarta Composite Index, JCI, atau JSX) merupakan salah satu indeks pasar saham yang digunakan oleh Bursa Efek Indonesia (BEI). Diperkenalkan pertama kali pada tanggal 1 April 1983, sebagai indikator pergerakan harga saham di Bursa Efek Jakarta (BEJ), indeks ini mencakup pergerakan harga seluruh saham biasa dan saham preferen yang tercatat di BEI. Saat ini terdapat 383 perusahaan yang sahamnya tercatat di BEI. 
Menurut Widoatmodjo (2000, p189), Indeks Harga Saham Gabungan merupakan pintu dan permulaan pertimbangan seseorang untuk melakukan investasi, sebab dari indeks harga saham inilah investor mengetahui situasi secara umum, sebab indeks harga saham merupakan ringkasan dari dampak simultan dan kompleks atas berbagai macam faktor yang berpengaruh terutama faktor-faktor ekonomi. Bahkan sekarang indeks harga saham dapat dijadikan barometer kesehatan ekonomi suatu negara.

Indeks Harga Saham Gabungan di BEI dihitung dengan menggunakan metode rata-rata tertimbang harga pasar (market value weighted average index), dimana harga pasar adalah harga saham terakhir yang terjadi di bursa. Widoatmodjo (2000, p196) menyatakan bahwa dasar pemberian bobot pada perhitungan IHSG tertimbang ditentukan oleh besar kecilnya pengaruh yang dberikan saham tersebut. Bagi saham yang sangat berperan dalam mempengaruhi pasar, akan diberi bobot besar. Sebaliknya saham yang kecil pengaruhnya akan diberi bobot kecil. Tambahnya, dalam menentukan besar kecilnya bobot dipengaruhi oleh besar kecil jumlah saham yang didaftarkan emiten.

Dari sumber website IHSG (http://www.idx.co.id/), didapat informasi bahwa Bursa Efek Jakarta (BEJ) berawal dengan dibukanya sebuah bursa saham oleh pemerintah Hindia Belanda pada 1912 di Batavia. Setelah sempat tutup beberapa kali karena terjadinya perang, BEJ kembali dibuka pada 1977 di bawah pengawasan Bapepam. Pada tanggal 13 Juli 1992, BEJ diprivatisasi dengan dibentuknya PT. Bursa Efek Jakarta atau dikenal juga dengan Jakarta Stock Exchange (JSX) dan kemudian pada tahun 1995, perdagangan elektronik di BEJ dimulai dengan jumlah emiten yang menurut Cahyono dalam bukunya yang berjudul: "Investing in JSX now?" (2002, p126) mencapai 316 pada tahun 2001.

Setelah sempat jatuh ke sekitar 300 poin pada saat-saat krisis, BEJ mencatat rekor tertinggi baru pada awal tahun 2006 setelah mencapai level 1.500 poin berkat adanya sentimen positif dari dilantiknya presiden baru, Susilo Bambang Yudhoyono. Peningkatan pada tahun 2004 ini sekaligus membuat BEJ menjadi salah satu bursa saham dengan kinerja terbaik di Asia pada tahun tersebut. 
Demi efektivitas operasional dan transaksi, Pemerintah memutuskan untuk menggabung Bursa Efek Jakarta sebagai pasar saham dengan Bursa Efek Surabaya sebagai pasar obligasi dan derivatif. Bursa hasil penggabungan ini mulai beroperasi pada 1 Desember 2007 dengan nama Bursa Efek Indonesia (BEI) atau Indonesian Stock Exchange (IDX) dengan emiten yang berjumlah 393 dan dengan kapitalisasi pasar sekitar 1,8 triliun rupiah. BEI menggunakan sistem perdagangan bernama Jakarta Automated Trading System (JATS) sejak 22 Mei 1995, menggantikan sistem manual yang digunakan sebelumnya. Sistem JATS ini sendiri direncanakan akan digantikan sistem baru yang akan disediakan OMX. Penggabungan ini menjadikan Indonesia hanya memiliki satu pasar modal.

Untuk memberikan informasi yang lebih lengkap tentang perkembangan bursa kepada publik, BEI menyebarkan data pergerakan harga saham melalui media cetak dan elektronik. Satu indikator pergerakan harga saham tersebut adalah indeks harga saham.

Saat ini, BEI mempunyai tujuh macam indeks saham:

1. IHSG, menggunakan semua saham tercatat sebagai komponen kalkulasi Indeks sebanyak 334 emiten.

2. Indeks Sektoral, menggunakan semua saham yang masuk dalam setiap sektor (sejumlah 9 sektor) yang didalamnya terdapat seluruh emiten yang terdaftar dalam BEI.

3. Indeks LQ45, menggunakan 45 saham terpilih setelah melalui beberapa tahapan seleksi.

4. Indeks Individual, yang merupakan Indeks untuk masing-masing saham didasarkan nilai dasar (yaitu 100).

5. Jakarta Islamic Index, merupakan gabungan 30 emiten dalam satu indeks perdagangan saham syariah.

6. Indeks Papan Utama dan Papan Pengembangan, indeks yang didasarkan pada kelompok saham yang tercatat di BEI yaitu kelompok Papan Utama yang berjumlah 123 emiten dan Papan Pengembangan yang berjumlah 211 emiten.

7. Indeks Kompas 100, menggunakan 100 saham pilihan harian Kompas.

Menurut The Wharton School of the university of Pennsylvania (http://www-stat.wharton.upenn.edu/), Dow Jones Industrial Average (DJIA) adalah salah satu indeks pasar saham yang didirikan oleh editor 
The Wall Street Journal dan pendiri Dow Jones \& Company yaitu Charles Dow. Dow membuat indeks ini sebagai suatu cara untuk mengukur performa komponen industri di pasar saham Amerika Serikat (AS). DJIA secara resmi dimulai sejak 26 Mei 1896. Saat ini DJIA merupakan salah satu indeks pasar saham AS tertua yang masih berjalan. Pada awalnya di tahun 1896 terdapat 12 perusahaan yang terdaftar di DJIA. Jumlah keanggotaan bursa kemudian diperbanyak menjadi 20 pada tahun 1916, yang pada akhirnya ditambahkan menjadi 30 perusahaan sejak tahun 1928 hingga sekarang. Editor koran The Wall Street Journal memilih perusahaan mana yang akan dikeluarkan dan dimasukkan ke dalam bursa. Sekarang, bursa saham ini terdiri dari 30 perusahaan terbesar di Amerika Serikat yang sudah secara luas go public. Untuk mengkompensasi efek pemecahan saham dan penyesuaian lainnya, sekarang ini perhitungan indeks menggunakan weighted average. bukan rata-rata aktual dari harga saham komponennya. Indeks DJIA merupakan indeks yang paling sering digunakan sebagai acuan keadaan pasar saham di AS atau New York Stock Exchange (NYSE).

Homepage FTSE (http://www.ftse.com) mendefinisikan indeks FTSE atau The Financial Times Stock Exchange adalah indeks saham di Bursa Saham London yang dimiliki Grup FTSE, dimana pada awalnya merupakan joint venture antara Financial Times dan Bursa Saham London. Dimulai sejak 3 Januari 1984 dan terus berkembang sampai sekarang menjadi 4 macam indeks , yaitu:

1. FTSE 100 Index, terdiri dari 100 saham perusahaan terbesar yang mewakili 81\% kapitalisasi pasar Bursa Saham London.

2. FTSE 250 Index, terdiri dari 250 perusahaan terbesar berikutnya setelah 100 di atas.

3. FTSE 350 Index, terdiri dari gabungan saham pada FTSE 100 Index dan FTSE 250 Index.

4. FTSE SmallCap Index, yang terdiri dari saham-saham perusahaan diluar dari FTSE 350, yaitu saham-saham dengan kapitalisasi pasar kecil.

Dari keempat indeks di atas yang menjadi acuan dalam pasar saham internasional adalah FTSE 100 Index. Penghitungan FTSE 100 menggunakan perhitungan free float method. 
Homepage Hangseng (http://www.hangseng.com) mendefinisikan indeks Hangseng sebagai sebuah indeks pasar saham berdasarkan kapitalisasi di Bursa Saham Hongkong. Indeks ini digunakan untuk mendata dan memonitor perubahan harian dari perusahaan-perusahaan terbesar di pasar saham Hongkong dan sebagai indikator utama dari performa pasar di Hongkong. Indeks ini dimulai sejak 24 November 1969. Indeks ini dibuat dan dikembangkan oleh HSI Services Limited, yang merupakan anak perusahaan dari Bank Hangseng, bank terbesar ke-2 di Hongkong. Anggota dari indeks ini adalah 45 emiten yang memiliki kapitalisasi pasar terbesar di Bursa Saham Hongkong, ke-45 perusahaan tersebut mewakili $67 \%$ kapitalisasi pasar di bursa ini.

Terdapat beberapa indeks saham lainnya di Bursa Saham Hong Kong, seperti Hangseng China AH Index Series, Hangseng China Enterprises Index, Hangseng China H-Financials Index, Hangseng Composite Index Series, Hangseng Freefloat Index Series and Hangseng Total Return Index Series, tetapi tertingal jauh dalam popularitas jika dibandingkan dengan indeks Hangseng. Perhitungan indeks Hangseng menggunakan Market Capiltalization - Weighted.

Menurut Investor Saham (www.investorsaham.com) Nikkei225 merupakan indeks pasar saham yang mengacu pada Tokyo Stock Exchange. Indeks Nikkei ini merupakan indeks yang paling banyak digunakan dalam pasar saham Asia. Indeks tersebut dikalkulasi harian oleh koran Nihon Keizai Shimbun (Nikkei) sejak tahun 1971, dimana indeks ini terisi oleh 225 perusahaan yang dipilih oleh koran Nikkei. Ratarata harga tertimbang dan komponen-komponennya ditinjau ulang per tahun.

Nikkei225 memulai perhitungannya pada 7 September 1950, dan melakukan kalkulasi ulang secara retroaktif pada 16 Mei 1949. Saham yang masuk ke dalam Nikkei225 dihitung dengan memberikan bobot tertimbang yang setara berdasarkan pada nilai par 50 yen per lembar saham. Nikkei225 dirancang untuk menggambarkan pasar secara keseluruhan, sehingga tidak terdapat kecenderungan pada salah satu industri tertentu. 
Rata-rata indeks saham Nikkei225 turun 3,3 persen menjadi 12.433,4, yang merupakan penutupan terendahnya dalam 2,5 tahun terakhir pada 13 Maret 2008. Hal ini dipengaruhi oleh nilai dolar yang menurun secara berkelanjutan dan permasalahan pada ekonomi Amerika Serikat. Indeks Nikkei225 kembali turun 4,5 persen pada awal sesi perdagangan sore menjadikan indeks sebesar 11.691 .00 poin, yang adalah rekor terendah sejak Juli 2005 pada 17 Maret 2008, setelah JPMorgan Chase mengumumkan akan membeli bank investasi Amerika yang bermasalah yakni Bear Sterns, yang menunjukkan pada investor betapa dalamnya dampak dari krisis subprime mortgage.

Saham-saham yang terdapat pada indeks Nikkei225 di-review tahunan, dan pengumuman hasil review dilakukan pada bulan September. Apabila diperlukan perubahan akan dilakukan pada awal Oktober. Sementara itu, perubahan dapat dilakukan setiap saat apabila saham yang bersangkutan tidak dapat terdaftar lagi di bursa (misalnya terkena delisting). Setiap perubahan yang akan dilakukan diumumkan pada koran Nikkei

Website Straittimes (http://www.straitstimes.com/) mengartikan Indeks Straits Times atau biasa disebut dengan STI sebagai:

"market value-weighted stock market index based on the stocks of 30 representative companies listed on the Singapore Exchange. Launched in the wake of a major sectoral re-classification of listed companies by the Singapore Exchange, which saw the removal of the "industrials" category, the STI replaced the Straits Times Industrials Index (STII), and began trading 31 August 1998 at 885.26 points, in continuation of where the STII left off. Then, it represented $78 \%$ of the average daily traded value over a 12month period and $61.2 \%$ of total market capitalisation on the exchange."

Pengertian tersebut dapat diterjemahkan sebagai berikut:

"nilai pasar index tertimbang yang didasari oleh 30 perusahaan perwakilan yang terdaftar dalam bursa saham Singapura. Diterbitkan dalam perkembangan secara besarbesaran dalam klasifikasi ulang perusahaan atas dihapuskannya kategori industry dalam bursa saham 
Singapura. STI menggantikan STII dan mulai diperdagangkan pada tanggal 31 Agustus 1998 di angka 885.26, sebagai kelanjutan atas STII yang digantikannya. Setelah itu STI merepresentasikan $78 \%$ dari rata-rata nilai tukar harian dalam periode 12 bulan dan $61.2 \%$ dari total kapitalisasi pasar dalam bursa.”

Berdasarkan pengertian di atas dapat disimpulkan bahwa Indeks Straits Times adalah indeks dalam perdagangan saham di bursa Singapura yang didalamnya terdapat 30 perusahaan yang merupakan perwakilan dari pasar saham Singapura. Penghitungan indeks ini menggunakan weighted average dimana indeks STII atau Straits Times Industrial Index telah dimulai sejak tahun 1966, sebelum digantikan dengan index STI pada tanggal 31 Agustus 1998 yang merupakan acuan pasar saham di bursa Singapura hingga saat ini.

\section{METODOLOGI PENELITIAN}

Hipotesis yang diuji dalam penelitian ini adalah sebagai berikut:

$\mathrm{Ho}_{1}$ : Indeks Dow Jones, indeks FTSE, indeks Nikkei, indeks Strait Times, dan indeks Hangseng secara bersama-sama tidak mempunyai pengaruh signifikan terhadap JSX

$\mathrm{Ho}_{2}$ : Indeks Dow Jones tidak mempunyai pengaruh signifikan terhadap JSX dan JSX tidak mempunyai pengaruh signifikan terhadap indeks Dow Jones

$\mathrm{Ho}_{3}$ : Indeks FTSE tidak mempunyai pengaruh signifikan terhadap JSX dan JSX tidak mempunyai pengaruh signifikan terhadap indeks FTSE

$\mathrm{Ho}_{4}$ : Indeks Nikkei tidak mempunyai pengaruh signifikan terhadap JSX dan JSX tidak mempunyai pengaruh signifikan terhadap indeks Nikkei

$\mathrm{Ho}_{5}$ : Indeks Strait Times tidak mempunyai pengaruh signifikan terhadap JSX dan JSX tidak mempunyai pengaruh signifikan terhadap indeks Strait Times 
$\mathrm{Ho}_{6}$ : Indeks Hangseng tidak mempunyai pengaruh signifikan terhadap JSX dan JSX tidak mempunyai pengaruh signifikan terhadap indeks Hangseng

$\mathrm{Ho}_{7}$ : Indeks Dow Jones, indeks FTSE, indeks Nikkei, indeks Strait Times, dan indeks Hangseng secara bersama-sama tidak mempunyai pengaruh signifikan terhadap IDX

$\mathrm{Ho}_{8}$ : Indeks Dow Jones tidak mempunyai pengaruh signifikan terhadap IDX dan IDX tidak mempunyai pengaruh signifikan terhadap indeks Dow Jones

$\mathrm{Ho}_{9}$ : Indeks FTSE tidak mempunyai pengaruh signifikan terhadap IDX dan IDX tidak mempunyai pengaruh signifikan terhadap indeks FTSE

$\mathrm{Ho}_{10}$ : Indeks Nikkei tidak mempunyai pengaruh signifikan terhadap IDX dan IDX tidak mempunyai pengaruh signifikan terhadap indeks Nikkei

$\mathrm{Ho}_{11}$ : Indeks Strait Times tidak mempunyai pengaruh signifikan terhadap IDX dan IDX tidak mempunyai pengaruh signifikan terhadap indeks Strait Times

$\mathrm{Ho}_{12}$ : Indeks Hangseng tidak mempunyai pengaruh signifikan terhadap IDX dan IDX tidak mempunyai pengaruh signifikan terhadap indeks Hangseng

Dibentuknya hipotesis-hipotesis di atas didasarkan atas terbentuknya Indeks Harga Saham Gabungan (IHSG) Jakarta yang baru (IDX) dengan ditambahkannya emiten-emiten dari pasar Surabaya ke dalam IHSG Jakarta yang lama (JSX). Selain itu, dengan adanya kasus Subprime Mortgage yang terjadi di Amerika dimana mempengaruhi bursa-bursa di seluruh dunia, maka penelitian ini bertujuan untuk mengetahui apakah indeks bursa Amerika DowJones berpengaruh terhadap indeks bursa Indonesia (JSX dan IDX) begitupula sebaliknya. Indeks bursa di luar Amerika yang terkena dampak juga diteliti sehingga dapat memberikan gambaran terperinci tentang indeks manakah (diantara DowJones, FTSE, Nikkei, STI, dan/atau HANGSENG) yang berpengaruh terhadap IHSG (JSX dan IDX) dan berlaku sebaliknya untuk mengetahui apakah indeksindeks tersebut dipengaruhi oleh IHSG (JSX dan IDX) baik secara bersamaan maupun individual. Uji hipotesis tersebut dilakukan dengan periode pengambilan data dari 1 Januari 2006 sampai 30 Juni 2009. 


\section{HASIL}

Hubungan dengan indeks internasional yang berada dalam regional yang berbeda dapat dilihat dari tabel berikut ini:

Tabel 1. Hubungan indeks internasional beda regional

\begin{tabular}{|c|c|c|c|}
\hline No. & Indeks & Hubungan dengan JSX & Hubungan dengan IDX \\
\hline 1. & $D J I$ & $\begin{array}{l}\text { Hubungan } 1 \text { arah } \\
\text { terbalik dimana kenaikan } \\
\text { DJIA akan berpengaruh } \\
\text { pada penurunan JSX }\end{array}$ & $\begin{array}{l}\text { Hubungan } 2 \text { arah dimana } \\
\text { kenaikan DJIA } \\
\text { mempengaruhi penurunan } \\
\text { IDX dan sebaliknya } \\
\text { kenaikan IDX } \\
\text { berpengaruh positif } \\
\text { terhadap kenaikan DJIA }\end{array}$ \\
\hline 2. & FTSE & $\begin{array}{l}\text { Hubungan } 1 \text { arah } \\
\text { terbalik dimana kenaikan } \\
\text { FTSE akan menyebabkan } \\
\text { penurunan pada JSX }\end{array}$ & $\begin{array}{l}\text { Hubungan } 1 \text { arah searah } \\
\text { dimana IDX memiliki } \\
\text { pengaruh positif terhadap } \\
\text { FTSE }\end{array}$ \\
\hline
\end{tabular}

Dari hasil di atas dapat disimpulkan bahwa hubungan indeks internasional yang berbeda regional dengan Indonesia memiliki hubungan terbalik dengan JSX dan IDX memberikan pengaruh yang positif terhadap indeks tersebut. Hal ini dapat dikaitkan dengan kondisi saat terjadi Subprime Mortgage JSX terpengaruh secara negatif karena saat indeks luar tersebut mengalami kenaikan, kondisi ekonomi di negara berkembang seperti di Indonesia sedang mengalami perlambatan ditandai dengan meningkatnya harga bahan pokok dan likuiditas yang berkurang.

Hubungan dengan indeks internasional yang berada dalam satu regional dapat dilihat dari tebel berikut: 
Tabel 2.Hubungan indeks internasional dalam satu regional

\begin{tabular}{|c|c|c|c|}
\hline No. & Indeks & Hubungan dengan JSX & $\begin{array}{l}\text { Hubungan dengan } \\
\text { IDX }\end{array}$ \\
\hline 1. & N225 & $\begin{array}{l}\text { Hubungan } 1 \text { arah searah } \\
\text { dimana kenaikan JSX } \\
\text { berpengaruh terhadap } \\
\text { kenaikan N225 }\end{array}$ & 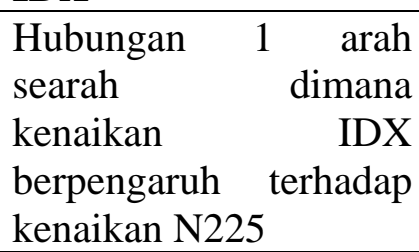 \\
\hline 2. & STI & 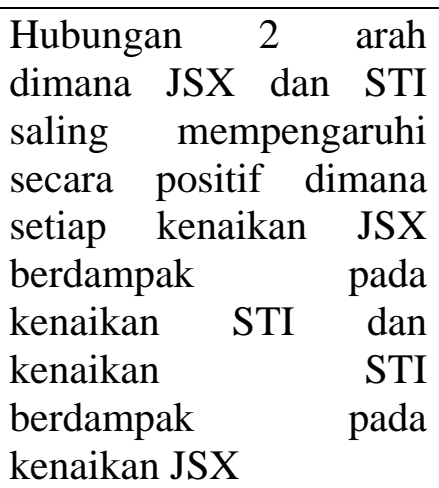 & 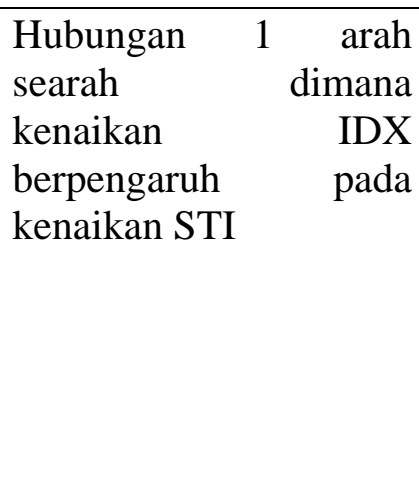 \\
\hline 3. & HANGSENG & $\begin{array}{lr}\text { Hubungan } 1 \text { arah searah } \\
\text { dimana } & \text { kenaikan } \\
\text { HANGSENG } & \\
\text { berdampak } & \text { pada } \\
\text { kenaikan JSX } & \\
\end{array}$ & $\begin{array}{l}\text { Hubugan } 1 \text { arah searah } \\
\text { dimana kenaikan IDX } \\
\text { berpengaruh positif } \\
\text { terhadap kenaikan } \\
\text { HANGSENG }\end{array}$ \\
\hline
\end{tabular}

Sedangkan untuk indeks dalam satu regional yang sama terjadi hubungan yang searah dikarenakan kemiripan kondisi ekonomi dan hubungan kerjasama yang erat antara negara-negara dalam regional yang sama. Pengaruh Indonesia yang menguat terhadap negara-negara lain dalam satu regional Asia disebabkan karena ketahanan ekonomi Indonesia yang lebih baik dibandingkan dengan negara-negara lain, yang salah satunya dapat dinilai dari terpilihnya menteri keuangan Indonesia menjadi yang terbaik di Asia. 


\section{KESIMPULAN}

Berdasarkan pengujian dan analisis yang telah dilakukan pada bab sebelumnya, maka dapat ditarik kesimpulan sebagai berikut:

1. Variabel independen DJIA, FTSE, N225, STI, dan HANGSENG tidak dapat dibuat pemodelan dengan JSX dan IDX secara simultan, karena terdapat korelasi yang kuat antara sesama variabel independen atau terdapat multikolinearitas, dimana hasil yang diperoleh untuk ketiga variabel independen adalah koefisien yang tidak signifikan untuk tingkat keyakinan 95 \%. Jadi dalam penelitian ini dibuat pemodelan untuk masing-masing variabel independen terhadap variabel dependen.

2. Variabel independen DJIA mempunyai pengaruh yang signifikan terhadap variabel terikat JSX dengan tingkat keyakinan $95 \%$, sehingga $\mathrm{Ho}_{2}$ yang menyatakan bahwa DJIA tidak mempunyai pengaruh yang signifikan terhadap JSX ditolak, tetapi sebaliknya JSX tidak mempunyai pengaruh yang signifikan terhadap DJIA. Hal ini menunjukan developed market, yang diwakili DJIA, memiliki pengaruh yang signifikan terhadap emerging market, yang diwakili JSX.

3. Hipotesa $\mathrm{Ho}_{8}$ yang menyatakan bahwa DJIA tidak memiliki pengaruh yang signifikan terhadap IDX ditolak, begitu pula dengan IDX yang memiliki pengaruh terhadap DJIA dilihat dari hasil uji granger yang menandakan hubungan keduanya adalah hubungan dua arah. Pemulihan dari krisis yang cepat menyebabkan bursa Indonesia juga mempengaruhi bursa Amerika karena pemulihan ekonomi di Indonesia mempengaruhi pemulihan ekonomi di Amerika dengan meningkatnya daya beli Indonesia sehingga impor dari negara-negara lain termasuk Amerika meningkat.

4. Variabel independen FTSE mempunyai pengaruh yang signifikan terhadap variabel terikat JSX dengan tingkat keyakinan $95 \%$, sehingga $\mathrm{Ho}_{3}$ yang menyatakan bahwa FTSE tidak mempunyai pengaruh yang signifikan terhadap JSX ditolak, tetapi sebaliknya JSX tidak mempunyai pengaruh yang signifikan terhadap FTSE. Hal ini menunjukan developed market, yang diwakili FTSE, memiliki pengaruh yang signifikan terhadap emerging market, yang diwakili JSX.

5. Hipotesa $\mathrm{Ho}_{9}$ yang menyatakan bahwa Indeks FTSE tidak mempunyai pengaruh signifikan terhadap IDX dan IDX tidak mempunyai 
pengaruh signifikan terhadap indeks FTSE ditolak karena meskipun FTSE tidak memiliki pengaruh signifikan terhadap IDX, tetapi IDX memiliki pengaruh signifikan terhadap FTSE. Dengan karakteristik ekonomi Inggris yang menyerupai Amerika, maka bursa Indonesia dapat mempengaruhi bursa Inggris pada pertengahan pertama tahun 2009 dengan indikasi meningkatnya daya beli Indonesia sehingga nilai impor dari negara lain meningkat.

6. Variabel independen N225 mempunyai pengaruh yang signifikan terhadap variabel terikat JSX dengan tingkat keyakinan $95 \%$, sehingga $\mathrm{Ho}_{4}$ yang menyatakan bahwa N225 tidak mempunyai pengaruh yang signifikan terhadap JSX ditolak, karena JSX mempunyai pengaruh yang signifikan terhadap N225. Dengan lebih dari 1,000 perusahaan Jepang yang beroperasi di Indonesia menunjukkan bahwa bursa Jepang jelas dipengaruhi bursa Indonesia karena setiap terjadi gejolak ataupun peningkatan daya beli di Indonesia akan berdampak langsung pada 1,000 perusahaan Jepang tersebut sehingga secara tidak langsung akan mempengaruhi bursa Jepang.

7. Begitupula halnya dengan $\mathrm{Ho}_{10}$ yang menyatakan bahwa Indeks N225 tidak mempunyai pengaruh signifikan terhadap IDX dan IDX tidak mempunyai pengaruh signifikan terhadap indeks N225 ditolak karena meskipun indeks N225 tidak memiliki pengaruh signifikan terhadap IDX, tetapi IDX memiliki pengaruh signifikan terhadap indeks N225. Seiring dengan mengeratnya hubungan Jepang dan Indonesia yang ditandai dengan bertambahnya angka produksi mobil-mobil perusahaan Jepang di Indonesia juga menegaskan pengaruh bursa Indonesia terhadap Jepang yang sedang terkena dampak Subprime Mortgage.

8. Variabel independen STI mempunyai pengaruh yang signifikan terhadap variabel terikat JSX dengan tingkat keyakinan $95 \%$, sehingga $\mathrm{Ho}_{5}$ yang menyatakan bahwa STI tidak mempunyai pengaruh yang signifikan terhadap JSX ditolak, dan JSX mempunyai pengaruh yang signifikan terhadap STI. Banyaknya perusahaan Indonesia yang memiliki pasar Eropa dan Amerika membuka kantor cabang di Singapura, sehingga investasi dari Indonesia tentunya mempengaruhi kenaikan bursa Singapura. Ditambah lagi dengan letak geografis yang berdekatan sehingga tidak sedikit penduduk Indonesia yang bekerja ataupun menaruh investasi di Singapura. Hubungan keduanya adalah 
hubungan 2 arah saling mempengaruhi karena apabila terjadi goncangan ekonomi di Indonesia secara tidak langsung akan menyebabkan penambahan investasi penduduk Indonesia di Singapura yang menyebabkan kenaikan bursa Singapura, sebaliknya bila di Singapura terjadi goncangan yang menyebabkan bursa Singapura turun maka penduduk Indonesia yang berinvestasi di Singapura akan merasakan dampak penurunan investasi mereka secara tidak langsung yang menyebabkan penurunan laba atau daya beli di Indonesia sehingga terjadi penurunan pada bursa Indonesia.

9. Hipotesa $\mathrm{Ho}_{11}$ yang menyatakan bahwa Indeks STI tidak mempunyai pengaruh signifikan terhadap IDX dan IDX tidak mempunyai pengaruh signifikan terhadap indeks STI ditolak karena IDX memiliki pengaruh signifikan terhadap indeks STI. Dengan resistensi Indonesia terhadap krisis global, bursa Singapura tidak lagi mempengaruhi bursa Indonesia karena di Indonesia terjadi kestabilan ekonomi dan di Singapura tidak, sehingga para investor tentunya mengurangi investasi mereka di Singapura. Dengan berkurangnya investor Indonesia di Singapura menghilangkan pengaruh Singapura terhadap bursa Indonesia. Hal ini dikuatkan dengan melemahnya hubungan bilateral kedua negara terkait kasus impor pasir, sehingga pada pertengahan pertama tahun 2009 bursa Singapura dipengaruhi oleh bursa Indonesia akibat ketergantungan impor bahan baku dari Indonesia yang bertetangga dengan Singapura yang disebabkan keterbatasan sumber daya Singapura.

10. Variabel independen HANGSENG mempunyai pengaruh yang signifikan terhadap variabel terikat JSX dengan tingkat keyakinan 95 $\%$, sehingga $\mathrm{Ho}_{6}$ yang menyatakan bahwa HANGSENG tidak mempunyai pengaruh yang signifikan terhadap JSX ditolak. Sebelum terjadi krisis Subprime Mortgage dan krisis Dubai, negara China sangat mempengaruhi Indonesia dinilai dari angka impor produk China yang sangat besar sehingga bursa China pun mempengaruhi bursa Indonesia secara tidak langsung. Tingginya angka impor Indonesia ini bukan disebabkan oleh daya beli yang baik, tetapi disebabkan oleh kebutuhan Indonesia akan barang-barang produksi China yang lebih murah, akibatnya ketergantungan Indonesia terhadap produk-produk China tersebut membuat bursa Indonesia dipengaruhi oleh bursa China. 
11. Hipotesa $\mathrm{Ho}_{12}$ yang menyatakan bahwa Indeks HANGSENG tidak mempunyai pengaruh signifikan terhadap IDX dan IDX tidak mempunyai pengaruh signifikan terhadap indeks HANGSENG ditolak karena IDX memiliki pengaruh signifikan terhadap indeks HANGSENG. Seiring terjadinya krisis Subprime Mortgage dan krisis Dubai, pabrik-pabrik di China berguguran yang menyebabkan penurunan bursa yang mencapai titik terendah di penghujung tahun 2008. Pada tahun 2009 bursa China terangkat akibat pengaruh positif dari bursa Indonesia dimana kestabilan ekonomi di Indonesia mendorong peningkatan impor dan mendorong perubahan ketergantungan dimana sejak tahun 2009 pabrik di China yang bergantung dengan angka impor Indonesia karena banyaknya pabrik yang ditutup dan keadaan ekonomi di China yang menurun. Karena perubahan ketergantungan tersebut, maka sejak tahun 2009 bursa Indonesia melalui IDX lebih berpengaruh terhadap bursa China melalui HANGSENG.

12. Pengaruh DJIA dan FTSE terhadap JSX adalah negatif atau berbanding terbalik dimana jika DJIA / FTSE naik maka JSX turun. Ini menandakan bahwa kenaikan DJIA dan FTSE akan menekan JSX.

13. DJIA dengan IDX memiliki hubungan yang saling mempengaruhi dimana DJIA mempengaruhi IDX secara negatif tetapi IDX mempengaruhi DJIA secara positif, sedangkan IDX mempengaruhi FTSE secara positif.

14. JSX dan IDX mempengaruhi N225 secara positif dimana saat keduanya mengalami kenaikan akan berdampak pada kenaikan indeks N225. Begitupula halnya dengan indeks HANGSENG yang memiliki karakteristik yang menyerupai N225 dimana pengaruh JSX dan IDX terhadapnya adalah pengaruh yang positif.

15. JSX dan STI memiliki hubungan yang simultan, dimana JSX mempengaruhi STI secara positif dan STI mempengaruhi JSX secara positif. Artinya jika JSX naik maka STI naik begitu pula jika STI naik maka JSX naik. Sedangkan IDX mempengaruhi STI secara positif dimana kenaikan IDX memicu kenaikan STI.

Penelitian ini dilakukan ketika krisis subprime mortgage melanda AS yang mengakibatkan terjadinya krisis keuangan global dan pada saat bursa-bursa Asia mengalami penguatan di tengah pelemahan bursa Amerika dan Eropa. Hal ini dilakukan untuk mengetahui secara jelas 
apakah terdapat pengaruh yang signifikan dari developed markets yang diwakili oleh negara-negara yang merupakan pusat investasi di regionalnya dan terkena dampak langsung dari subprime mortgage terhadap pergerakan JSX yang merupakan emerging market dan tidak terkena dampak panjang subprime mortgage secara langsung.

\section{Rekomendasi}

Berdasarkan hasil penelitian dan pengaruh keterbatasan yang ada, maka peneliti ingin memberikan beberapa saran dan rekomendasi yang mungkin dapat dilakukan untuk penelitian selanjutnya agar hasil penelitian yang diperoleh bisa lebih akurat. Saran-saran tersebut antara lain:

1. Penelitian berikutnya diharapkan menambah faktor-faktor regional dari dalam negeri seperti fluktuasi harga saham tujuh penggerak aktif JSX dan IDX yang lebih dikenal dengan 'the seven brothers' yaitu: BUMI, UNSP, BTEL, BNBR, ELTY, ENRG, dan DEWA

2. Penelitian berikutnya diharapkan menambah indeks dari bursa internasional lainnya sebagai variabel independen, karena sangat dimungkinkan indeks lain yang tidak dimasukkan dalam penelitian ini berpengaruh terhadap pergerakan JSX dan IDX;

3. Penelitian berikutnya diharapkan memperluas objek penelitian berupa faktor-faktor kuantitatif seperti nilai tukar rupiah, harga komoditas dunia, dan Gross Domestic Product;

4. Penelitian berikutnya diharapkan memperluas objek penelitian berupa faktor-faktor non-kuantitatif seperti stabilitas sosial dan politik, tingkat pendidikan, dan tingkat keamanan dari negara-negara yang dijadikan sampel;

5. Praktisi dan pengamat sebaiknya menggunakan indeks asing yang paling mempengaruhi indeks Indonesia sebagai acuan, karena menggunakan berbagai indeks, terlebih membandingkan secara bersama-sama, sebagai acuan akan membingungkan dan tidak akurat.

6. Dengan hasil penelitian ini yang menunjukkan bahwa indeks Indonesia memiliki pengaruh lebih besar terhadap bursa lain, maka untuk pengamat dan praktisi disarankan untuk menganalisa dan mempertimbangkan faktor internal atau faktor dalam negeri sebagai acuan utama. 


\section{Keterbatasan}

Penelitian ini memiliki beberapa keterbatasan, yaitu jumlah sampel yang digunakan dalam penelitian ini hanya JSX, IDX, DJIA, FTSE, N225, STI, dan HANGSENG. Selain itu, penelitian ini menggunakan dua periode pengamatan, yaitu periode 1 Januari 2006 - 31 Desember 2008 untuk variabel tetap JSX dan periode 1 Januari 2009 - 30 Juni 2009 untuk variabel tetap IDX. Selanjutnya dalam penelitian ini, pengaruh yang diperhitungkan hanya berasal dari indeks di bursa internasional saja, sedangkan masih banyak faktor-faktor ekonomi lainnya yang dapat mempengaruhi pergerakan JSX dan IDX baik yang berasal dari luar negeri maupun dalam negeri, baik yang bersifat kuantitatif maupun yang bersifat non-kuantitatif.

\section{DAFTAR PUSTAKA}

Berk, Jonathan \& DeMarzo, Peter. (2007). Corporate Finance. USA: Prentice Hall.

Cahyono, Jaka E. (2002). Investing in JSX now?. Jakarta: Elex Media Komputindo.

Ferari, Sonny A.md. (2009). Apa Itu Investasi?, Retrieved November 21, 2009, from : http://sonny.ohlog.com/d.2009.1.3.html

Jogiyanto, H.M. (2003). Teori Portofolio dan Analisis Investasi. Yogyakarta: BPFE.

Markowitz, Harry M. (1991). Portofolio Selection: Efficient Diversivication of Investment. USA: Blackwell publishers, Inc, Massachusetts.

Siamat, Dahlan. (2004). Manajemen lembaga keuangan. Jakarta: LPFEUI.

T., Darmadji, HM \& Fakhruddin. (2006). Pasar Modal Di Indonesia: Pendekatan Tanya Jawab. Jakarta: Salemba Empat. 
Uribe, Martin. (2006). A Fiscal Theory of Sovereign Risk. Journal of Monetary Economics, 53(8), 1857-1875. Elsevier-National Bureau of Economic Research, Inc, Massachusetts, USA.

Widoatmodjo, Sawidji \& Blikolong, J.B. (2000). Cara Sehat Investasi di Pasar Modal: Pengetahuan Dasar. Jakarta: Jurnalindo Aksara Grafika.

Widiawati, Nani. (2009). Hubungan Bilateral \& Multilateral Indonesia. Retrieved February 21, 2010 from: http://naniwidiawati.blogspot.com/2009/04/hubungan-bilateralmultirateral.html

Winarno, Wing Wahyu. (2007). Analisis Ekonometrika dan Statistika dengan Eviews. Yogyakarta: UPP STIM YKPN. 